\title{
MENEROBOS SEKAT ADMINISTRASI PERADILAN
}

\author{
Indra Rahmatullah \\ Dosen Fakultas Syariah dan Hukum \\ UIN Syarif Hidayatullah Jakarta \\ Korespondensi: indra.r86@gmail.com
}

\begin{abstract}
Abstrak
Sebagai bagian dari reformasi peradilan yang sedang dilaksanakan, reformasi manajemen perkara atau administrasi perkara menjadi salah satu bagian yang menjadi fokus perubahan. Reformasi pada manajemen perkara tidak dapat dinafikan karena untuk mendapatkan hasil proses hukum yang fair dimulai dari manajemen perkara yang baik. Jika manajemen perkara peradilan tidak dibenahi secara serius maka akan banyak celah-celah hukum yang dimanfaat oleh pihak-pihak yang tidak bertanggungjawab untuk mencoba mengintervensi pada sebuah proses hukum yang sedang berjalan. Namun demikian, reformasi administrasi peradilan nampaknya belum menunjukkan hasil yang efektif. Masih ada beberapa contoh kasus korupsi yang memanfaatkan celah administrasi manajemen perkara. Padahal Mahkamah Agung telah melakukan studi banding dengan Federal Court of Australia (FCA) tahun 2013 tentang bagaimana manajemen administrasi perkara yang modern. Untuk itu dibutuhkan terobosan-terobosan program dan gagasan baru baik dari aturannya, SDM dan infrastruktur yang memadai.
\end{abstract}

Kata-kata kunci: Reformasi Peradilan; Manajemen Administrasi Perkara; Korupsi.

\begin{abstract}
As a part of the judicial reformation which is being implemented, the reformation of case management or case adminitrastion become significant issue in case of judicial reformation. The reformation of case management should not to be regardless because to get fair judicial process begun with a good case management. If the reformation of case management not to be reformed, there will be many legal loopholes that can be used by ocnums to disturb fair judicial process. However, the judicial reformation is still not shows a significant progress and effective. There are still many corruption cases because of many legal loopholes. In the other hand, The Supreme Court had been doing a comparative study how to implement a modern case management with Federal Court of Australia (FCA) in 2013. To reform all problems, we need legal breakthroughs and new ideas as follows rules, human resources and good infrastructures.
\end{abstract}

Keywords: Judicial Reformation; Administration of Case Management; Corruption. 


\section{PENDAHULUAN}

Untuk memberikan rasa keadilan di masyarakat, badan peradilan semestinya harus menjadi garda terdepan sebagai institusi yang memberikan rasa keadilan. Namun demikian, tugas itu nyatanya belum terealisasi dengan baik. Banyak celahcelah di peradilan khususnya mengenai manajemen administrasi perkara yang sering menjadi celah hukum sehingga dapat dimanfaatkan oleh oknum-oknum yang tidak bertanggungjawab.

Salah satu masalah yang sangat penting dalam upaya perbaikan sistem peradilan dan penegakan hukum dan keadilan di Indonesia adalah masalah manajemen administrasi perkara. Persoalan ini nampaknya masalah yang remeh temeh namun jika dibiarkan masalah ini menjadi pintu masuk praktik-praktik korupsi yang selama ini menimpa nasib peradilan di Indonesia.

Tebalnya birokrasi perkara itu dimanfaatkan oleh oknum-oknum penegak hukum sendiri yang mencari keuntungan pribadi dan golongan sehingga pekerjaan rumah reformasi birokrasi yang telah dicanangkan dan ditetapkan tak pernah berhasil dan tak pernah tuntas. Alih-alih ingin melakukan reformasi birokrasi jadi tertunda.

Bahkan, lebih ironis lagi adalah jika ada sikap resistensi dari kalangan intern yang dengan sengaja ikut melakukan boikot jika ada usaha- usaha reformasi birokrasi demi terwujudnya institusi peradilan yang bersih, transparan dan akuntabel. Jaringan-jaringan oknum dibuat sedemikian rupa sehingga apapun usaha demi kebaikan akan terus tumpul. Ada beberapa kasus yang memperlihat bagaimana celah manajemen administrasi perkara itu dimanfaatkan oknum-oknum yang tidak bertanggungjawab.

Pertama, pada Mei tahun 2016 terkuak kasus dagang perkara atau makelar kasus (Markus) yang dilakukan oleh Kasubdit Kasasi Mahkamah Agung (MA) Andri Tristyanto. Sebagai Kasubdit, Andri menjadi makelar kasus dengan modus menunda-nunda salinan berkas perkara sehingga menghambat proses eksekusi dan mengatur majelis hakim sesuai pesanan demi menghindari hakim agung yang terbiasa memutus vonis berat kepada koruptor. Dengan berbekal uang suap Rp. 200 Juta, Andri dapat melakukan manipulasi berkas perkara dengan cara menunda-nunda pengiriman salinan putusan kasasi sehingga terdakwa tidak segera dieksekusi oleh Jaksa dan dapat mengatur majelis Hakim Agung pesanan yang membayarnya.

Bahkan dalam persidangan beberapa fakta terungkap, adanya sekelompok orang alias "geng" yang bisa mengatur perkara di MA. Andri sendiri diketahui bermain sebagai "gelandang" yang bertugas mengolah kepentingan berbagai pihak yang ingin perkaranya segera dibereskan di MA. Andri mem- 
punyai "kewenangan" cukup besar di luar tugasnya. Ia diketahui bisa membantu memonitor berbagai perkara di MA mulai dari pidana umum, pidana khusus, hingga Tata Usaha Negara (TUN).

Kedua, kasus Mario C. Bernardo pada tahun 2013. Advokat dari Kantor Hukum Hotma Sitompoel \& Associates, terjaring Operasi Tangkap Tangan (OTT) Komisi Pemberantasan Korupsi (KPK). Kasus suap ini bermula saat Direktur PT Grand Wahana Indonesia, Koestanto Harijadi Widjaja, melaporkan Hutomo ke Polda Metro Jaya pada 5 Juli 2011. Dia dilaporkan dengan tuduhan melakukan penipuan dalam pengurusan Izin Usaha Pertambangan di Kabupaten Kampar Riau. Dalam putusannya, Pengadilan Negeri Jakarta Selatan menyatakan Hutomo bersalah. Namun menurut majelis perbuatannya bukan tindak pidana melainkan perdata, sehingga ia dilepaskan dari segala tuntutan hukum atau Ontslag Van Recht Vervolging.

Lantaran tak puas atas vonis tersebut, pihak Grand Wahana meminta bantuan hukum kepada kantor pengacara Hotma Sitompoel \& Associates, tempat Mario bekerja, pada Januari 2013. Singkat cerita, Mario meminta bantuan Djodi (staf MA) pada 25 Juni 2013. Djodi lalu memberikan informasi bahwa majelis hakim yang menangani Hutomo adalah Gayus Lumbun, Andi Abu Ayyub Saleh, dan Zaharuddin Utama. Tak hanya memberikan informasi, Djodi juga menemui Suprapto, staf hakim Ayyub. Djodi dan
Suprapto bersepakat akan meminta imbalan Rp 200 juta kepada Mario.

Djodi lalu menyerahkan memori kasasi jaksa kepada Suprapto pada 2 Juli 2013 di kantor MA. Keesokannya, Suprapto mengatakan dia sanggup membantu mengurus perkara itu tapi dananya minta ditambah Rp 300 juta. Mario menyanggupi permintaan itu. Uangnya diberikan secara bertahap kepada Djodi. Pada penyerahan ketiga yang dilakukan pada 25 Juli 2013, Djodi kemudian dicokok oleh KPK.

Pengadilan Tindak Pidana Korupsi Jakarta memvonis advokat Mario C. Bernardo selama empat tahun penjara. Hakim menyatakan, bekas anak buah Hotma Sitompoel ini terbukti menyuap staf MA, Djodi Supratman, untuk mengurus perkara kasasi yang ditangani di MA.

Ketiga, Hakim Harini Wijoso pada tahun 2005. Harini ditangkap KPK karena upaya penyuapan terhadap Ketua MA saat itu, Bagir Manan yang kebetulan menjadi hakim ketua kasus yang melibatkan pengusaha ProboSutedjo.

Selain Harini, lima pegawai MA juga turut terseret dalam perkara ini. Mereka antara lain Sriyadi (anggota staf Direktorat Perdata MA), Malam Pagi Sinuhadji (Kepala Bagian Kepegawaian MA), Pono Waluyo (staf bagian kendaraan MA), Suhartoyo (Wakil Sekretaris Korpri MA), dan Sudi Ahmad (staf Suhartoyo di Korpri MA).

Harini Wijoso, terdakwa dalam upaya penyuapan Ketua MA Bagir Manan, oleh majelis hakim Pengadil- 
an Tindak Pidana Korupsi (Tipikor), divonis empat tahun penjara dan denda Rp150 juta subsider enam bulan kurungan. Putusan ini jauh dari tuntutan penuntut umum Komisi Pemberantasan Korupsi (KPK) sebelumnya yang menuntut delapan tahun penjara.

Jika kondisi demikian terus menerus, para pencari keadilan frustasi dengan lembaga peradilan kita sehingga tak jarang memberikan efek negatif seperti enggannya masyarakat untuk mengurus perkaranya atau bahkan lebih ironi lagi masyarakat kita sudah skeptis akan hal mengurus masalahnya di pengadilan.

Belum lagi masalah-masalah pada institusi-institusi hukum di tanah air yang menghadapi persoalan-persoalan administrasi dan manajemen seperti kurang responsif, cenderung ketinggalan zaman dalam menghadapi perkembangan dalam masyarakat yang menuntut akses keadilan (access to justice) yang lebih adil, berkepastian dan pelayanan hukum (legal services) yang lebih efisien dan terbuka.

\section{PEMBAHASAN}

\section{Memperburuk Citra Peradilan}

Tak ayal lagi bahwa dengan beberapa kejadian di atas membawa dampak negatif pada wajah penegak hukum kita. Parahnya adalah justru pegawai di lingkungan peradilan ternyata ikut bermain dalam praktik kotor itu. Data hasil jajak pendapat Kompas Juni 2016 menunjukkan bahwa kondisi peradilan mengalami penurunan tingkat kepercayaan dari masyarakat secara drastis. ${ }^{1}$

\begin{tabular}{lcc}
\hline \multicolumn{1}{c}{ Respon Masyarakat } & $\begin{array}{c}\text { Setuju } \\
\text { (\%) }\end{array}$ & $\begin{array}{c}\text { Tidak } \\
\text { Setuju } \\
\text { (\%) }\end{array}$ \\
\hline Gaji hakim kurang memadai & 18,9 & 76,5 \\
Mafia peradilan tetap marak & 81,1 & 14,5 \\
Masih terbukanya peluang suap & 82,7 & 15,0 \\
Vonis terhadap aparat hukum kurang berat & 82,7 & 13,7 \\
Sistem pengawasan hakim lemah & 83,9 & 11,7 \\
Mental hakim masih buruk & 86,5 & 9,9 \\
\hline
\end{tabular}

Dari data tersebut menunjukkan bahwa masalah peradilan kita cukup kompleks karena persepsi ketidakpercayaan responden masih tinggi kepada peradilan saat ini. Masalahmasalah seperti gaji hakim kurang memadai, mafia peradilan masih marak, terbukanya peluang suap, vonis pada aparat hukum kurang berat, sistem pengawasan hakim lemah dan mental hakim masih buruk masih dapat nilai raport merah.

Nampaknya citra peradilan kita saat ini yang masih dapat raport merah bukan sendirian. Secara global memang wajah penegakan hukum di Indonesia masih belum beranjak juga dari persepsi yang buruk. Dari jajak pendapat tahun 2015 juga tidak jauh berbeda dari tahun 2016 tadi. $^{2}$

Nilai dari kepuasan publik terhadap institusi penegak hukum baru sampai pada nilai 60 (enam puluh) sampai dengan 64 (enam puluh empat)

Berdasarkan hasil jajak pendapat yang dilakukan oleh Harian Kompas periode Juni 2016.

Berdasarkan hasil jajak pendapat yang dilakukan oleh Harian Kompas periode Januari-Juli 2015. 
persen. Bahkan pada bulan April 2015 lalu, kepercayaan publik berada pada titik terendah yang hanya mencapai nilai 32 (tiga puluh dua) persen. Tentu data ini bukan kabar gembira bagi negara Indonesia yang notabene reformasi hukum adalah pekerjaan rumah yang paling utama dengan prinsip Rule of Law-nya.

Ironisnya, untuk negara yang memegang asas Rule of Law untuk kawasan Asia Tenggara saja, peringkat Indonesia terdampar di urutan ke 52 (lima puluh dua) masih di bawah Filipina yang ada di peringkat ke-50 (lima puluh), Malaysia 39 (tiga puluh sembilan), dan Singapura 9 (sembilan). ${ }^{3}$ Berikut 5 (lima) negara terbawah yaitu:

\begin{tabular}{lcc}
\hline Country & Score & $\begin{array}{c}\text { Global } \\
\text { Rangking }\end{array}$ \\
\hline Nepal & 0.53 & 49 \\
Panama & 0.53 & 48 \\
Belarus & 0.53 & 50 \\
Philipines & 0.53 & 51 \\
Indonesia & 0.52 & 52 \\
\hline
\end{tabular}

\section{Benang Kusut Administrasi Peradilan}

Peradilan adalah salah satu pilar dari prinsip-prinsip negara hukum yang menjadi pondasi dasar di Indonesia. Indonesia adalah negara hukum, negara hukum ialah negara yang susunannya diatur dengan sebaikbaiknya dalam undang-undang sehingga segi kekuasaan dari alat-alat pemerintahannya didasarkan hukum. Rakyat tidak boleh bertindak sendiri-sendiri menurut semaunya yang bertentangan dengan hukum. Negara hukum adalah negara yang diperintah bukan oleh orang-orang tetapi dengan undangundang. ${ }^{4}$

Dalam negara hukum, kekuasaan itu tidak tanpa batas karena negara berdasarkan hukum, sehingga kekuasaan tunduk pada hukum. Prinsip pokok penting dalam negara hukum adalah bahwa hukum memperlakukan sama di depan hukum, tanpa ada perbedaan atas ras, keturunan, agama, kedudukan sosial dan kekayaan. ${ }^{5}$

Konsep F. J. Stahl tentang negara hukum ditandai oleh 4 (empat) unsur pokok yaitu:

1. Pengakuan dan perlindungan terhadap hak asasi manusia

2. Negara didasarkan pada teori trias politica

3. Pemerintahan berdasarkan undangundang (wetmatig van bestuur)

4. Adanya peradilan administrasi negara yang bertugas menangani kasus melanggar hukum oleh badanbadan berwenang negara atau pemerintah (onrechmatig overheidsdaad). ${ }^{6}$

Sebagai salah satu pilar negara hukum, badan peradilan harus bersih

$3 \quad$ Berdasarkan survei dari World Justice Project tahun 2015. Survei ini dibuat untuk mengukur tingkat komitmen negara-negara di dunia khususnya di kawasan Asia Tenggara yang berkomitmen terhadap asas Rule of Law.

$4 \quad$ D’Mutiaras, Imu Hukum Tata Negara Umum (Pustaka Islam 1995) 20.

5 Mochtar Kusumaatmadja dan Arif B. Sidharta, Pengantar Ilmu Hukum, Suatu Pengenalan Pertama Ruang Lingkup Berlakunya Ilmu Hukum (Alumni 2000) 135.

6 Di negara-negara Anglo Saxon berkembang pula suatu konsep negara hukum yang semula dipelopori oleh A.V. Dicey dengan sebutan Rule of Law. Konsep ini menekankan pada beberapa 
dari setiap praktik korupsi, kolusi dan nepotisme (KKN). Celah praktik KKN tersebut salah satu penyebabnya dari panjangnya rantai birokrasi perkara di MA yang dapat menjadi celah hukum dan digunakan oleh oknum untuk melakukan dagang perkara. Hasil riset dari Lembaga Kajian dan Advokasi Independensi Peradilan mencatat ada tiga permasalahan yang menghinggapi administrasi peradilan di Indonesia. ${ }^{7}$

Pertama, Proses penanganan perkara terlalu panjang. Penanganan perkara di MA melewati kurang lebih 26 (dua puluh enam) tahapan, sejak berkas perkara diterima oleh biro umum sampai dengan dikirim kembali ke pengadilan pengaju. Berdasarkan Surat Keputusan Ketua MA No. 214 tentang jangka waktu penanganan perkara, jangka waktu penanganan perkara kasasi dan Peninjauan Kembali paling lama 250 (dua ratus lima puluh) hari. Alur panjang penanganan perkara adalah sebagai berikut:

A. Registrasi dan Penelahaan

Pengadilan Pengaju

1) Penerimaan dan pencatatan oleh Biro Umum

2) Pencatatan Subbag TU Dir. Pratalak

3) Penelaahan oleh Seksi Penelaahan Dit. Pratalak
4) Direktur Pratalak menyiapkan pengantar berkas ke Panitera Kamar

5) Staf TU panitera kamar mencatat berkas yang diterima dari Dit Pratalak

6) Staf pencatat register menelaah berkas perkara

7) Staf pencatat register meregister pada Buku Register (Buku Besar) Kepaniteraan Kamar.

B. Distribusi Perkara (Penetapan Majelis Hakim dan Panitera Pengganti/PP)

8) Staf pencatat register menyampaikan daftar perkara yang telah diregister kepada panitera kamar untuk disampaikan pada ketua kamar

9) Ketua kamar meneruskan daftar perkara kepada Ketua MA untuk mendapatkan disposisi delegasi pendistribusian perkara

10) Ketua kamar menetapkan majelis hakim untuk setiap perkara setelah mendapatkan disposisi dari Ketua MA

11) Panitera kamar menetapkan $P P$ setelah menerima penetapan Majelis Hakim dan menyerahkan berkas perkara kepada Ketua Majelis

12) Ketua Majelis Hakim menetapkan hari sidang musyawarah dan ucapan dan menyampaikan pada $\mathrm{PP}$

unsur yaitu: (1) Supremasi hukum (supremacy of law); (2) persamaan di hadapan hukum (equality before the law); (3) konstitusi yang didasarkan pada hak-hak perorangan (constitution based on individual rights). Muhammad Tahir Azhary, Negara Hukum, Suatu Studi Tentang Prinsip-Prinsipnya Dilihat dari Segi Hukum Islam, Implementasinya pada Periode Negara Madinah dan Masa Kini (Prenada Media 1991) 90.

7 Lihat Laporan Penelitian Lembaga Kajian dan Independensi Peradilan LeIP tahun 2015. 
13) PP menyerahkan salinan berkas (Bundel B) kepada para anggota majelis beserta penetapan hari sidang musyawarah

C. Pembacaan Berkas dan Musyawarah oleh Majelis Hakim

14) Anggota majelis membaca salinan berkas perkara pada saat yang sama

15) Seluruh anggota majelis hakim berkumpul dan memberikan pendapat hukumnya pada tanggal yang ditetapkan untuk pelaksanaan sidang musyawarah dan ucapan

16) PP mencatat amar putusan dan pertimbangan majelis untuk penyiapan naskah putusan

D. Penyiapan Naskah Putusan

17) Operator menyerahkan draft naskah putusan yang selesai diketik kepada PP

18) PP mengoreksi draft naskah putusan sebelum disampaikan kepada anggota majelis P1

19) PP menyerahkan naskah putusan yang sudah direvisi sesuai koreksi anggota majelis P1 kepada anggota majelis P2

20) PP menyerahkan naskah putusan yang sudah direvisi sesuai koreksi anggota majelis P2 kepada ketua majelis hakim (P3)

21) PP mengedarkan naskah putusan yang telah direvisi sesuai koreksi P3 untuk ditanda- tangani oleh seluruh anggota majelis hakim agung

22) PP mengirimkan naskah putusan yang telah ditandatangani oleh seluruh anggota majelis kepada panitera kamar

23) Staf tata usaha panitera kamar mencatat naskah putusan yang dikirim oleh PP

24) Staf panitera kamar menyiapkan surat pengantar untuk mengirimkan salinan putusan pada pengadilan pengaju

25) Staf kepaniteraan kamar mencatat tanggal surat pengantar dalam buku register kamar

26) Staf kepaniteraan kamar mengirimkan naskah putusan kepada pengadilan pengaju.

Kalau demikian panjangnya, tentu berlawanan dengan prinsip peradilan yang sederhana, cepat dan biaya ringan. ${ }^{8}$ Bahkan jika proses hukumnya tidak jelas dan terkatung-katung justru menunda-nunda sebuah keadilan yang pada akhirnya menjerumuskan pada proses yang tidak adil (justice delayed justice denied).

Menurut Immanuel Kant memandang peradilan cepat sebagai "Speedy administration of justice" yakni penyelesaian perkara yang cepat dan tuntas. Hal ini terlihat pada pendapat Imanuel Kant sebagai berikut: ${ }^{9}$

“........Speedy administration of justice atau peradilan cepat selalu didambakan oleh setiap pencari keadilan. Pada umumnya setiap pencari keadilan menginginkan penyelesaian perkara

Pasal 4 yat (2) Undang-Undang Nomor 48 Tahun 2009 Tentang Kekuasaan Kehakiman. Andi Hamzah, Pembaharuan Hukum Acara Pidana Indonesia (Sinar Grafika 2009) 37. 
yang cepat dan tuntas, mereka pada umumnya menginginkan penyelesaian perkara cepat dan tuntas walaupn akhirnya dikalahkan dari pada pemeriksaan yang bertele-tele, tertundatunda, sekalipun akhirnya dimenangkan juga perkaranya. Sudahlah wajar kalau para pencari keadilan menghendaki penyelesaian perkara yang cepat, kecuali ingin lekas tahu mengenai kepastian (hukum) hak-haknya dalam suatu perkara, pemeriksaan yang bertele-tele atau tertunda-tunda berarti mengeluarkan banyak biaya dan waktu. Tidak mengherankan ada ungkapan yang berbunyi justice delayed is justice denied".

Fenomena ini juga menjadi pemantik agar setiap aturan hukum tidak bersifat presisi. Analisis ekonomi menilai bahwa semakin tinggi tingkat presisi suatu aturan hukum, akan semakin besar biaya yang dikeluarkan untuk membuat aturan hukumnya. Dengan begitu, akan semakin tinggi juga biaya (cost) bagi rakyat pencari keadilan dalam mendapatkan hakhaknya. ${ }^{10}$

Mestinya sebuah aturan yang dibuat harus efektif sehingga dapat direspon langsung oleh masyarakat terkait karena memberikan insentif ekonomi terhadap kepatuhan akan aturan hukum tersebut. Aturan hukum yang direspon seperti itu akan memberikan dampak ekonomi yang menguntungkan bagi masyarakat. ${ }^{11}$

Oleh karenanya, setiap aturan yang berkaitan dengan administrasi peradilan hendaknya dan sudah se- harusnya dibuat sesederhana mungkin (simplifikasi perkara), efisien dan efektif sehingga memberikan keuntungan yang lebih kepada masyarakat luas dari segi waktu dan biaya. Semakin panjang rantai birokrasi, maka akan semakin mahal juga biaya yang akan dikeluarkan.

Kedua, Tersebarnya tanggungjawab administrasi penanganan perkara. Alur panjang tersebut melewati 3 (tiga) unit kerja yang berbeda-beda, yaitu Biro Umum, Direktorat Pranata dan Tata Laksana dan Kepaniteraan Muda. Kondisi ini menyulitkan dalam pertanggungjawaban atas administrasi dan penyelesaian perkara yang dapat menjadikan pengawasan perkara tidak efektif.

Ketiga, Pencatatan proses penanganan perkara belum sepenuhnya berbasis teknologi informasi. Penyelesaian perkara dari satu tahap ke tahapan berikutnya masih dicatat secara manual dengan buku ekspedisi perkara/register perkara. Kondisi ini sering dimanfaatkan oknum orang dalam MA untuk mengetauhi status perkaranya dan memanfaatkannya untuk "memperjual-belikan" informasi kepada pihak yang berperkara.

Padahal MA sebenarnya sudah melakukan studi banding ke Federal Court Australia (FCA) tahun 2014 tentang manajemen perkara untuk belajar bagaimana mengembangkan

\footnotetext{
10 Johnny Ibrahim, Pendekatan Ekonomi Terhadap Hukum; Teori dan Implikasi Penerapannya dalam Penegakan Hukum (ITS Press 2009) 63, 68.

$11 \quad$ Ibid. 68.
} 
$e$-court service yang terdiri atas $e$ lodgement, e-Court file, dan e-trial. Bahkan FCA tersebut sudah melakukannya kurang lebih 30 tahun lalu, untuk kepentingan pengelolaan perkara mereka memiliki aplikasi manajemen perkara yang disebut e-track. Sejak saat itulah Pengadilan Federal Australia sudah tidak lagi menggunakan buku register perkara. Namun hasil studi banding tersebut belum terlihat nyata di MA.

\section{Pembenahan Administrasi Peradilan}

Agar tidak merugikan para pencari keadilan, maka administrasi peradilan perlu direformasi. Pembenahan dimaksud supaya dapat meyakinkan kepada pencari keadilan bahwa proses hukum yang sedang ia jalani akan berjalan sesuai dengan peraturan perundang-undangan yang berlaku, tidak diintervensi oleh pihak manapun dan harus terbuka sehingga dapat diawasi oleh publik dan para pihak yang berperkara. ${ }^{12}$

Dalam pembenahan administrasi peradilan, menurut Jimly Ashiddiqie harus dimulai sejak pelaporan, pengaduan, ataupun pendaftaran pelayanan hukum sampai ke tahap eksekusi putusan dan pemasyarakatan merupakan satu kesatuan proses mulai dari terjadinya peristiwa hukum dalam masyarakat sampai terwujudnya keadaan atau terpulihkannya kembali keadilan dalam masyarakat. Dalam proses itu diperlukan adanya jaminan bahwa: ${ }^{13}$

a. Prosesnya berlangsung tepat dalam menjamin keadilan (justice) dan kepastian hukum (legal certainty);

b. Prosesnya berlangsung efisien, cepat dan tidak membebani para pihak di luar kemampuannya;

c. Menurut aturan hukumnya sendiri, yaitu berdasarkan peraturan perundang-undangan yang berlaku sejak sebelum perkara itu sendiri terjadi;

d. Secara independen tanpa campur tangan atau dipengaruhi oleh kepentingan-kepentingan politik dan ekonomi dari pihak-pihak lain atau kepentingan salah satu pihak dengan merugikan pihak yang lain; dan

e. Secara akuntabel dan transparan sehingga hasilnya dapat dipercaya oleh para pihak dan masyarakat pada umumnya.

Untuk mewujudkan keenam hal tersebut dalam praktik, ada beberapa faktor menentukan yang perlu mendapat perhatian, yaitu: ${ }^{14}$

a. Faktor Substansi Aturannya. Dalam hal ini yang paling menentukan adalah hukum acara yang diterapkan

$12 \quad$ Proses ini jika dilakukan, maka secara tidak langsung menjamin independensi kekuasaan kehakiman. Kekuasaan kehakiman merupakan kekuasaan yang merdeka untuk menyelenggarakan peradilan guna menegakkan hukum dan keadilan. Rimdan, Kekuasaan Kehakiman Pasca-Amandemen Konstitusi (Kencana Prenada Media Group 2012) 1.

13 Jimly Asshiddiqie, 'Reformasi Tata Kelola Peradilan',<http://www.jimly.com/makalah/namafile/ 63/REFORMASI_TATA_KELOLA_MANAJEMEN_PERADILAN.pdf >diakses 1 Desember 2016.

14 Ibid, 2-3. Senada dengan Jimly Ashiddiqie, untuk membenahi masalah pada institusi penegak hukum, diperlukan pembenahan yang holistik. Pembenahan holistik itu menurut Soerjono 
dalam semua proses peradilan perlu disempurnakan sesuai dengan kebutuhan zaman.

b. Faktor Sumber Daya Manusia. Baik panitera maupun petugas administrasi pada umumnya perlu terus menerus mengikuti perkembangan zaman, sehingga dapat bekerja efisien dan produktif. Demikian pula para hakim, dari waktu ke waktu harus pula terus menerus memutakhirkan diri dengan pengetahuan-pengetahuan baru tentang hukum dan peraturan perundangundangan yang berkembang sangat dinamis.

c. Faktor Sistem Informasi dan Komunikasi Hukum. Oleh karena dunia hukum dewasa ini sudah berkembang semakin kompleks, maka teknologi informasi dan komunikasi (ICT) harus dimanfaatkan dengan sebaik-baiknya dalam mengembangkan sistem administrasi dan manajemen, baik manajemen peradilan maupun manajemen kelembagaan.

d. Faktor Dukungan Sarana dan Prasarana serta Anggaran. Cara kerja peradilan harus dilengkapi dengan pelbagai sarana dan prasarana yang memadai. Prasarana bangunan, ruang persidangan, perlengkapan teknologi, sistem renumerasi dan fasilitas kesejahteraan yang memadai sangat diperlukan untuk menjamin kualitas dan produktivitas kerja peradilan.

e. Faktor Kepemimpinan. Yang sering diabaikan adalah pentingnya peran kepemimpinan dalam menyukseskan agenda perbaikan sistem dan iklim kerja di lembaga hukum. Ketua, Wakil Ketua, Sekretaris dan

Soekanto adalah sebagai berikut: a. Aturan hukumnya, b. Penegak hukumnya, c. Saranda dan fasilitas, d. Masyarakat dan e. Kebudayaan. Kelima faktor tersebut saling berkaitan erat karena merupakan esensi dari penegakan hukum serta juga merupakan tolok ukur dari efektivitas penegakan hukum. Lihat Soerjono Soekanto, Faktor-Faktor yang Mempengaruhi Penegakan Hukum (Rajawali 1983) 5-6. Hal ini juga disampaikan oleh Lawrence Friedman bahwa untuk mengefektifkan sebuah penegakan hukum ada 3 aspek yang penting untuk diperhatikan yaitu Structure, Subtance dan Legal Culture. Subtansi, mencakup dengan materi hukum yang identik dengan peraturan perundang-undangan dalam mendukung pelaksanaan penyelenggaraan pemerintahan dan pembangunan nasional yang bersumber pada Pancasila dan UUD Negara Republik Indonesia. Struktur, mencakup berbagai organisasi dan lembaga-lembaga yang mendukung jalannya suatu organisasi. Sedangkan budaya hukum, berkaitan dengan kesadaran hukum masyarakat. Friedman mengatakan "To begin with, the legal system has structure. The system is contantly changing: but part of it change at different speeds, and not every part changes as fast as certain other parts. There are persistent, long-term pattern-aspects of the system that were yesterday (or even in the last century) and will be around for along time to come. This is the structure of the legal system - its skeleton or framework, the durable part, which gives a kind of shape and definition to the whole. Another aspect of the legal system is its subtance. By this is meant the actual rules, norms, and behaviour patterns - the fact that the speed limit is fifty-five miles an hour, that burglars can be sent to prison, that "by law" a pickle maker has to list his ingredients on the label of the jar. The third component of a legal system, which is, in some ways, the least obvious: the legal culture. By this we mean people's attitudes toward law and the legal system - their beliefs, values, ideas, and expextations....the legal culture, in other words, is the climate of social tought and social force that determines how law is used, avoided, or abused". Lawrence M. Friedman, American Law an Introduction, (rev. ed.,;W.W. Norton \& Company 1998) 8-10. 
Panitera sangat menentukan berhasil tidaknya upaya-upaya perbaikan sistemik.

Oleh karena itu, perlu ada terobosan aturan hukum yang dapat memperpendek mata rantai birokrasi perkara dari tingkat pertama sampai dengan tingkat akhir. Karena dengan banyaknya birokrasi yang dilalui dapat menjadi celah hukum oleh orangorang yang tidak bertanggungjawab. ${ }^{15}$

Kemudian juga terus meningkatkan sistem online atau elektronik dalam manajemen perkara. Apalagi MA sejak tahun 2013 telah melakukan kerjasama dengan FCA dalam mewujudkan peradilan modern yang setara dengan peradilan di negara-negara maju di mana sistem peradilannya sudah berbasis elektronik.

Hal ini sudah termaktub dalam Cetak Biru MA Tahun 2010-2035 bahwa sudah ada rencana untuk memodernisasi manajemen perkara dengan 3 tahapan, yaitu: ${ }^{16}$

a. Keterbukaan dan revitalisasi sistem pelaporan (2015)

- Tranparansi putusan

- Transparansi informasi perkara

- Integrasi informasi perkara

- Pelaporan perkara berbasis elektronik b. Modernisasi manajemen perkara yang berorientasi pada pelayanan (2020)

- Migrasi manajemen perkara berbasis elektronik

- Pelayanan publik berbasis elektronik

- Simplifikasi administrasi perkara cepat

- Pelayanan hukum terintegrasi (2025)

- Integrasi dengan penegak hukum lain

- Pengadilan online

- Sistem login tunggal bagi advokat

Selain itu, MA juga harus menjaga agar tidak ada ketertutupan dalam semua perkara yang sedang diproses. Pengadilan memiliki karakteristik yang berbeda dengan lembaga negara lain di mana keterbukaan dan pemberian jaminan akses masyarakat terhadap informasi yang dikelola pengadilan menjadi sangat penting. Sejak lama, prinsip "pengadilan yang terbuka" atau "open court principle" menjadi salah satu prinsip utama dalam sistem peradilan di dunia. Hal ini dijamin dalam Pasal 10 Deklarasi Universal Hak Asasi Manusia yang menyatakan bahwa "setiap orang, dalam persamaan yang penuh, berhak atas peradilan yang adil dan terbuka oleh pengadilan yang bebas dan tidak memihak, dalam menetapkan hak

\footnotetext{
$\overline{15}$ Dalam Cetak Biru MA Tahun 2010-2035 sebenarnya sudah ada upaya melakukan penyederhanaan perkara dengan tujuan; a. Meningkatkan akses keadilan pada masyarakat, b. Mempercepat proses penyelesaian perkara, c. Menekan biaya berperkara dan d, mengurangi arus perkara ke tingkat kasasi. Mahkamah Agung, Cetak Biru Mahkamah Agung Tahun 20102035, 30.

16 Ibid.
} 
dan kewajiban-kewajibannya serta dalam setiap tuntutan pidana yang dijatuhkan kepadanya. ${ }^{17}$

Article 10

Everyone is entitled in full quality to a fair and public hearing by an independent and impartial tribunal, in the determination of his rights and obligations and of any criminal charge againts him.

Apalagi menjamin keterbukaan untuk publik sudah menjadi komitmen MA bahwa salah satu upaya badan peradilan untuk menjamin adanya perlakuan sama di hadapan hukum, perlindungan hukum, serta kepastian hukum yang adil adalah dengan memberikan akses kepada masyarakat untuk memperoleh informasi. Informasi yang berkaitan dengan penanganan perkara dan kejelasan mengenai hukum yang berlaku dan penerapannya di Indonesia sesuai dengan Pasal 28 D ayat 1 UUD NRI Tahun 1945, Pasal 13 dan Pasal 52 UU Nomor 48 Tahun 2009 tentang Kekuasaan Kehakiman. Dengan adanya keterbukaan yang selalu dijaga, maka jaminan untuk memperoleh fair trial bagi pencari keadilan, masyarakat luas serta semua media massa dapat mengamati, memantau, mengontrol dan bahkan mengkritisi proses hukum tersebut akan terpenuhi.

Harapan publik cukup besar terhadap reformasi manajemen perkara karena MA adalah benteng terakhir untuk mengadu nasib bagi orangorang yang membutuhkan keadilan. Tingginya harapan publik itu tergambarkan dalam sebuah jajak pendapat yang dilakukan Kompas pada Juni 2016, bahwa harus ada pembenahan sistem perkara, pengawasan dan sanksi yang tegas bagi penegak hukum yang melakukan pelanggaran hukum. ${ }^{18}$

\section{PENUTUP}

Dibutuhkan beragam aspek untuk mewujudkan reformasi peradilan di MA. Mulai dari SDM, aturan dan budaya hukumnya. Segi SDM patut dimulai melalui restrukturisasi berbagai posisi. Tidak boleh ada lagi jaringan-jaringan orang dalam yang menguasai dengan

\begin{tabular}{lcc}
\hline \multicolumn{1}{c}{ Jajak Pendapat } & \multicolumn{2}{c}{ Skor } \\
\cline { 2 - 3 } & Setuju & $\begin{array}{c}\text { Tidak } \\
\text { setuju }\end{array}$ \\
\hline $\begin{array}{l}\text { Hukuman Bagi aparat penegak hukum } \\
\text { yang terjerat kasus diperberat }\end{array}$ & $96,9 \%$ & $1,6 \%$ \\
$\begin{array}{l}\text { Mengganti semua pejabat tinggi di bidang } \\
\text { penegakan hukum }\end{array}$ & $53,4 \%$ & $39,7 \%$ \\
$\begin{array}{l}\text { Memperketat pengawasan } \\
\text { Menciptakan sistem penegakan hukum } \\
\text { yang menutup celah suap dan korupsi }\end{array}$ & $96,4 \%$ & $1,6 \%$ \\
\hline
\end{tabular}

17 Liza Farihah, 'Mendorong Keterbukaan Informasi di Pengadilan, dalam Bunga Rampai Kisah Masyarakat Sipil Tahun 2014'. <http://leip.or.id/wp-content/uploads/2015/10/LizaFarihah_Advokasi-Mendorong-Keterbukaan-Informasi-di-Pengadilan.pdf $>$ diakses 1 Desember 2016.

18 Berdasarkan hasil survei jajak pendapat yang dilakukan oleh Harian Kompas periode Juni 2016. 
waktu yang lama karena dengan menguasai pada wilayah tertentu dengan cukup lama akan membuat sel-sel jaringan yang menghambat reformasi birokrasi. Untuk itu, dibutuhkan orang-orang yang fresh dan berkomitmen yang mengisi pada jabatan tertentu.

Proses mutasi, rolling jabatan dalam hal reformasi merupakan salah satu cara agar sirkulasi manajemen perkara dapat berjalan dengan orang-orang yang qualified. Hal ini dimulai dari pucuk pimpinan di MA yang dibarengi dengan sistem pengawasan internal yang melekat.

Segi aturan perlu disederhanakan atau perlu dicanangkan dengan konsisten melakukan simplifikasi perkara yang tidak memakan proses dan waktu yang terlalu lama. Jaring rantai birokrasi perlu dimodernisasikan dengan perkembangan teknologi saat ini. Cara-cara manual yang kerapkali menjadi celah kemudian dimanfaatkan oleh pihak yang tidak bertanggunjawab perlu ditambal dengan sistem manajemen perkara yang modern atau manajemen perkara berbasis elektronik.

Apalagi MA sudah melakukan perbandingan infrastruktur manajemen perkara ke FCA beberapa waktu lalu. Dengan perubahan manajemen berbasis elektronik sistem pengawasan akan lebih mudah karena pengawasan tidak lagi berpangku kepada pihak intern saja akan tetapi semua pihak dapat mengawasi secara terbuka.
Terakhir adalah dari segi budaya. Kultur "kalau bisa dipersulit mengapa dipermudah" seringkali menjadi stempel birokrasi di Indonesia. MA harus bisa menghilangkan kutukan birokrasi lama dan rumit karena menundanunda keadilan sama saja dengan mendatangkan sebuah ketidakadilan dan ketidakadilan itu akhirnya adalah pangkal dari semua musibah.

Jika kondisi itu berlarut-larut, institusi penegak hukum akan kehilangan wibawanya, masyarakat akan frustasi dan apatis terhadap nasib hukum dan akan muncul "pengadilan-pengadilan di jalanan" serta tindakan main hakim sendiri yang mengarah pada kondisi chaos di masyarakat.

Satu hal yang penting adalah pembenahan reformasi di MA harus cepat untuk diubah mengingat citra buruk yang masih menghinggapi dunia peradilan saat ini. Masalah birokrasi adalah hal yang kecil dan remeh temeh, namun apabila hal kecil tersebut tidak serius untuk diperbaiki maka akan menjadi bola es yang menyebabkan keruntuhan profesionalisme dan integritas MA yang susah payah telah dibangun selama ini.

\section{DAFTAR BACAAN}

\section{Buku}

Azhary, Muhammad Tahir, Negara Hukum, Suatu Studi Tentang PrinsipPrinsipnya Dilihat dari Segi Hukum Islam, Implementasinya pada Periode Negara Madinah dan Masa Kini (Prenada Media, 1991). 
D’Mutiaras, Ilmu Hukum Tata Negara Umum (Pustaka Islam 1995).

Friedman, Lawrence M., American Law an Introduction W.W. Norton \& Company 1998).

Hamzah, Andi, Pembaharuan Hukum Acara Pidana Indonesia (Sinar Grafika 2009).

Ibrahim, Johnny, Pendekatan Ekonomi Terhadap Hukum; Teori dan Implikasi Penerapannya dalam Penegakan Hukum (ITS Press 2009).

Kusumaatmadja, Mochtar dan Arif B, Pengantar Ilmu Hukum, Suatu Pengenalan Pertama Ruang Lingkup Berlakunya Ilmu Hukum (Alumni 2000).

Mahkamah Agung, Cetak Biru Mahkamah Agung Tahun 2010-2035.

Rimdan, Kekuasaan Kehakiman PascaAmandemen Konstitusi (Kencana Prenada Media Group 2012).

Soekanto, Soerjono. Faktor-Faktor yang Mempengaruhi Penegakan Hukum, (Rajawali 1983).

\section{Penelitian}

Jajak pendapat Harian Kompas periode Juni 2016.

Jajak pendapat Harian Kompas periode Januari-Juli 2015.

Laporan Penelitian Lembaga Kajian dan Independensi Peradilan (LeIP) Tahun 2015.

\section{Internet}

Asshiddiqie, Jimly. "Reformasi Tata Kelola Peradilan", <http://ww.jimly. com/makalah/namafile/63/REFOR MASI_TATA_KELOLA_MANAJEMEN_ PERADILAN.pdf.>

Liza Farihah, "Mendorong Keterbukaan Informasi di Pengadilan", Bunga Rampai Kisah Masyarakat Sipil Tahun 2014. File diunduh di <http://leip.or.id/wp-content/ u ploads / $2015 / 10 / \mathrm{Liza-}$ Farihah_Advokasi-MendorongKeterbukaan-Informasi-diPengadilan.pdf> 